\title{
Peran Advokat Sebagai Penegak Hukum Dalam Mendukung Terwujudnya Sistem Peradilan Pidana Terpadu Dalam Penegakan Hukum Pidana Di Indonesia
}

\section{Setyo Langgeng*}

Advokat, Mahasiswa Program Magister (S2) Ilmu Hukum Fakultas Hukum UNISSULA Semarang, email : Sylalaw@gmail.com)

\begin{abstract}
Abstrak
Keberadaan Advokat sebagai penegak hukum telah diatur didalam Pasal 5 Undang-undang Republik Indonesia Nomor 18 Tahun 2003 tentang Advokat. Namun, mengenai bagaimana bentuk dan tempat nyata peran Advokat sebagai penegak hukum masih samar, khususnya dalam perannya sebagai komponen pendukung terwujudnya sistem peradilan pidana terpadu, akibatnya penegakan hukum pidana di Indonesia belum optimal. Penelitian ini menggunakan metode penelitian hukum normatif atau studi kepustakaan, yaitu dengan menganalisa UU.RI. No. 18 tahun 2003 tentang Advokat dan UU.RI No. 8 tahun 1981 tentang Hukum Acara Pidana (KUHAP), serta peraturan perundang-undangan lainya dan bahan pustaka yang terkait dengan peran Advokat guna menjawab permasalahan. Hasil penelitian menunjukan bahwa dari segi bentuk dan tempatnya, terdapat 2 (dua) peran Advokat sebagai penegak hukum, yaitu (1) Peran Advokat dalam bentuk pendampingan hukum terhadap pelaku berdasar Pasal 54 KUHAP, (2) Peran Advokat dalam bentuk pendampingan hukum terhadap korban yang diatur diluar KUHAP. Diharapkan sebagai bahan masukan bagi penegak hukum dalam penegakan hukum dan keadilan di Idonesia.
\end{abstract}

Kata kunci : Advokat, Penegak Hukum, Sistem Peradilan Pidana Terpadu

\begin{abstract}
Absract
The existence of Advocates as law enforcement has been regulated in Article 5 of Law of the Republic of Indonesia Number 18 Year 2003 regarding Advocate. However, regarding how the form and the real place of the Advocate role as law enforcement is still vague, especially in its role as a supporting component of the establishment of integrated criminal justice system, consequently the enforcement of criminal law in Indonesia is not optimal yet. This research uses normative legal research method or literature study, that is by analyzing UU.RI. No. Law No. 18 of 2003 on Advocates and Law no. 8 of 1981 on Criminal Procedure Code (KUHAP), as well as other legislation and library materials related to the role of Advocates in order to answer the problem. The result of research shows that in terms of form and place, there are 2 (two) Advocates role as law enforcers, namely (1) Role of Advocate in the form of legal assistance to the perpetrator based on Article 54 KUHAP, (2) Role of Advocate in the form of legal assistance to the victims is regulated outside the Criminal Procedure Code. It is expected to be an input for law enforcement in law enforcement and justice in Indonesia.
\end{abstract}

Keywords : Advocate, Law Enforcement, Integrated Criminal Justice System

\section{PENDAHULUAN}

Indonesia telah lahir secara sah dan merdeka sebagai sebuah bangsa sejak diproklamirkan kemerdekaan Indonesia itu pada tanggal 17 Agustus 1945. Agar rancang bangun pendirian negara dengan tujuan untuk mewujudkan masyarakat Indonesia yang adil dan makmur itu bisa tercapai, maka tugas selanjutnya adalah membangun bangsa dan watak bangsa (Nation And Character Building) 
termasuk membangun hukum khususnya melaksanakan penegakan hukum di Indonesia

Penegakan hukum terus berjalan, tapi perubahan paradigma hukum pasca reformasi merupakan fenomena yang sangat berpengaruh terhadap percaturan politik dan kehidupan ketatanegaraan di Indonesia. Tetapi di sisi lain hukum belum sepenuhnya mampu menjadi pemenuh dahaga di tengah hausnya akan keadilan dan kesejahteraan rakyat. Masih banyak sekali kasus-kasus hukum yang belum terselesaikan dengan tuntas sehingga berpengaruh terhadap kepercayaan rakyat pada penegakan hukum. Fenomena seperti itu telah banyak menimbulkan perdebatan, khususnya terkait pemikiran relevansi penegakan hukum dengan nilai-nilai keadilan sosial dan kesejahteraan masyarakat ${ }^{1}$ Dengan adanya kondisi tersebut diperlukan peningkatan peran penegak hukum dalam penegakan hukum,

Dalam Bab I Pasal 1 Ayat (3) UUD 1945 menegaskan, bahwa, "Indonesia berdasar atas hukum (rechtsstaat) dan tidak berdasarkan kekuasaan belaka (machtsstaat)". Sebagai konsekwensi dari prinsip negara hukum, menuntut antara lain adanya jaminan kesederajatan bagi setiap orang di hadapan hukum (equality before the law). Oleh karena itu, Undang-Undang Dasar juga menentukan bahwa setiap orang berhak atas pengakuan, jaminan, perlindungan dan kepastian hukum yang adil serta perlakuan yang sama di hadapan hukum.

Dalam usaha mewujudkan prinsip-prinsip negara hukum dalam kehidupan bermasyarakat dan bernegara, peran dan fungsi Advokat sebagai profesi yang bebas, mandiri dan bertanggung jawab merupakan hal yang penting, di samping lembaga peradilan dan instansi penegak hukum seperti kepolisian dan kejaksaan. Melalui jasa hukum yang diberikan, Advokat menjalankan tugas profesinya demi tegaknya keadilan berdasarkan hukum untuk kepentingan masyarakat pencari keadilan, termasuk usaha memberdayakan masyarakat dalam menyadari hak-hak fundamental mereka di depan hukum. Advokat sebagai salah satu unsur sistem peradilan merupakan salah satu pilar dalam menegakkan supremasi hukum dan hak asasi manusia. Selain dalam proses peradilan, peran Advokat juga terlihat di jalur profesi di luar pengadilan. Kebutuhan jasa hukum Advokat di luar proses peradilan pada saat sekarang semakin meningkat, sejalan dengan semakin berkembangnya kebutuhan hukum masyarakat terutama dalam memasuki kehidupan yang semakin terbuka dalam pergaulan antar bangsa. Melalui pemberian jasa konsultasi, negosiasi maupun dalam pembuatan kontrak-kontrak dagang, profesi Advokat ikut memberi sumbangan berarti bagi pemberdayaan masyarakat serta pembaharuan hukum nasional khususnya di bidang ekonomi dan perdagangan, termasuk dalam penyelesaian sengketa di luar pengadilan.

Meminjam istilah dari Lawrence $M$ Friedman bahwa sistem hukum terdiri dari tiga elemen yaitu, substansi hukum, struktur hukum dan budaya hukum. Advokat sebagai struktur hukum dan subjek penegak hukum memiliki peran penting dalam sistem peradilan pidana dalam penegakan hukum pidana.

Mengenai keberadaan Advokat telah diatur dalam Pasal 1 Ayat (1) UURI No.18 Tahun 2003 tentang Advokat (UU. Advokat), "Advokat adalah orang yang berprofesi memberi jasa hukum, baik di dalam maupun di luar pengadilan yang memenuhi persyaratan berdasarkan ketentuan UndangUndang". Pasal 1 ayat (2) UU. Advokat menyebutkan, "Jasa Hukum adalah jasa yang diberikan Advokat berupa memberikan konsultasi hukum, bantuan hukum, menjalankan kuasa, mewakili, mendampingi, membela, dan melakukan tindakan hukum lain untuk kepentingan hukum klien". Pasal 1 Ayat (2) UU Advokat menyebutkan "Klien adalah orang, badan hukum, atau lembaga lain yang menerima jasa hukum dari Advokat", Sedangkan Pasal 5 ayat (1) UURI No.18 Tahun 2003 tentang Advokat,

\footnotetext{
${ }^{1}$ Gunarto, Agenda Penegakan Hukum dan Relevansinya Bagi Pembangunan Bangsa, Jurnal Pembaharuan Hukum Volume I, No.1, Januari-April 2014, h. 1.
} 
menyebutkan, bahwa, "Advokat berstatus sebagai penegak hukum, bebas dan mandiri yang dijamin oleh hukum dan peraturan perudang-undangan".

Advokat adalah profesi yang sangat terhormat (noble officium). Mengenai peran Advokat sebagai penegak hukum sejatinya masih ada yang beranggapan adanya ambevalensi terhadap profesi Advokat, disatu pihak Advokat dianggap profesi yang menghalangi kerja aparat, disisi lain, siapa lagi yang dapat menolong orang yang sedang berpekara dalam pengadilan kalau bukan Advokat.

Penegakan hukum pidana idealnya dilaksanakan dengan melibatkan semua komponen atau unsur penegak hukum (Polisi, Jaksa dan Hakimt) berdasar Sistem Peradilan Pidana Terpadu (SPPT) / Integrated Criminal Justice System (ICJS). Penegakan hukum pidana di Indonesia dilakukan berdasar UURI No.8 Tahun 1981 tentang Kitab Undang Undang Hukum Acara Pidana (KUHAP).

Menurut Barda Nawawi Arief $^{2}$, Sistem peradilan pada hakikatnya identik dengan sistem penegakan hukum, karena proses peradilan pada hakekatnya suatu proses menegakkan hukum. Jadi pada hakekatnya identik dengan "sistem kekuasaan kehakiman" karena "kekuasaan kehakiman" pada dasarnya merupakan "kekuasaan / kewenangan menegakkan hukum". Apabiala difokuskan dalam bidang hukum pidana, dapatlah dikatakan bahwa "Sistem Peradilan Pidana" (dikenal dengan istilah SPP atau Criminal Justice System / CJS) pada hakekatnya merupakan "sistem penegakan hukum pidana" (SPHP) yang pada hakekatnya juga identik dengan "Sistem Kekuasaan Kehakiman di bidang Hukum Pidana" (SKK-HP). Apabila SPP dilihat sebagai sistem kekuasaan kehakiman menegakkan hukum pidana (atau sistem kekuasaan kehakiman di bidang hukum pidana maka SPP merupakan serangkaian perwujudan dari kekuasaan menegakkan hukum pidana yang terdiri dari 4 (empat) sub sistem, yaitu : (1) kekuasaan penyidikan oleh lembaga penyidik; (2) kekuasaan penuntutan oleh lembaga penuntut umum; (3) kekuasaan mengadili/menjatuhkan putusan oleh badan peradilan; dan (4) kekuasaan pelaksanan hukum pidana oleh aparat pelaksana eksekusi. Keempat subsistem itu merupakan satu kesatuan sistem penegakan hukum pidana yang integral atau sering disebut dengan istilah Sistem Peradilan Pidana terpadu atau SPP terpadu atau Integrated Criminal Justice System. Patut dicatat bahwa didalam ke-4 sub-sistem itu, tentunya termasuk juga profesi Advokat sebagai salah satu penegak hukum

Rusli Muhammad menjelaskan bahwa posisi Advokat sebagai bagian atau sub sistem Sistem Peradilan Pidana Indonesia masih diperdebatkan, hal ini disebabkan karena belum adanya kejelasan wadah dan sturktur organisasi yang menyatu dan mengendalikan bekerjanya lembaga Advokat itu ${ }^{3}$.

Sistem peradilan pidana di dunia, baik itu yang menganut sistem hukum common law dan civil law masih berkutat pada karakteristik secara klasik yang dibedakan menjadi crime control dan due proces model, kedua model tersebut menggunakan model adversary system atau battle model ${ }^{4}$ dalam prosesnya kedua sistem itu menghadapkan kedua pihak dalam persidangan, yaitu pihak tersangka dan negara diwakili oleh penuntut umum untuk berpekara di sidang pengadilan.

Profesi hukum yang dikenal dengan Advokat secara teoritis tidak dikenal dan tidak dapat diartikan sebagai penegak hukum. ${ }^{5}$ ciri daripada penegak hukum sebagaimana pasal 1 United Nations Code of Conduct for Law Enforcement Officials, ialah memiliki hak untuk menangkap dan menahan, sedangkan Advokat disisi lain justru mencoba membebaskan, meringankan, merubah dan

\footnotetext{
${ }^{2}$ Barda Nawawi Arief, 2017. Reformasi Sistem Peradilan (Sistem Penegakan Hukum Di Indonesia), Badan Penerbit Univ. Diponegoro, Semarang hlm 2, 3, 7.

${ }^{3}$ Rusli Muhamad, 2012, Sistem Peradilan Pidana Indonesia : Dilengkapi Dengan 4 Undan-undang di Bidang Sistem Peradilan Pidana, UII Press, Yogyakarta, hlm. 31.

${ }^{4}$ Romli Atsasmita, 2011, Sistem Peradilan Pidana Kontemporer, cetakan ke 2, Kencana, Jakarta, hlm. Viiii.

${ }^{5}$ Komusi Yudisial, 2012, Dialektika Pembaharuan Sistem Hukum Indonesia, Komisi Yudisial, Jakarta, hlm. 82.
} 
menghindarkan dari semua tuntutan hukum tersebut.

Kedudukan Advokat sebagai penegak hukum telah diatur dalam pasal 5 Ayat (1) UU.RI No. 18 Tahun 2003 tentang Advokat. Peran Advokat / Penasehat Hukum sebagai bagian dari Pemberi Bantuan Hukum dalam Sistem peradilan Pidana diatur dalam UU.RI. No. 16 Tahun 2011 tentang Bantuan Hukum.

Bagir Manan, menerangkan, bahwa, "secara normatif, masalah Advokat sebagai penegak hukum telah selesai dengan adanya Undang-undang Advokat yang menegaskan bahwa Advokat merupakan penegak hukum, akan tetapi yang menjadi persoalan selanjutnya adalah bagaimana bentuk dan tempat nyata Advokat sebagai penegak hukum". ${ }^{6}$ khususnya dalam perannya sebagai komponen pendukung terwujudnya sistem peradilan pidana terpadu dalam penegakkan hukum pidana di Indonesia.

Dari uraian diatas, penulis memetakan permasalahan yang akan dibahas dalam jurnal tu sebagai berikut:

1. Bagaimana kedudukan Advokat sebagai penegak hukum dalam Sistem Peradilan Pidana di Indonesia?

2. Bagaimana peran Advokat sebagai penegak hukum dalam mendukung terwujudnya sistem peradilan pidana terpadu dalam penegakan hukum pidana di Indonesia?

\section{Metode Penelitian}

Jenis Penelitian yang digunakan adalah yuridis normatif, yakni menelaah berbagai peraturan perundang undangan dan bahan pustaka lainnya yang dapat membantu dalam menjelaskan kedudukan dan peran Advokat sebagai penegak hukum dalam mendukung terwujudnya Sistem Peradilan Pidana terpadu dalam penegakan hukum pidana di Indonesia. Pendekatan Penelitian yang digunakan adalah pendekatan perundang-undangan (statute-approach), yaitu dengan menelaah peraturan perundang-undangan dan regulasi ${ }^{7}$ yang bersangkut paut dengan isu hukum yang ditangani ${ }^{8}$ atau isu hukum yang diketengahkan. ${ }^{9}$

Bahan Hukum yang digunakan adalah berupa : 1) Bahan hukum primer, bahan hukum yang mengikat yakni peraturan perundang- undangan yang berkaitan dengan Advokat, yang meliputi : Undang-undang Republik Indonesia Nomor 8 Tahun 1981 tentang Kitab Undang Undang Hukum Acara Pidana (KUHAP), Undang-undang Republik Indonesia Nomor 18 Tahun 2003 tentang Advokat, Undang-undang Republik Indonesia Nomor 23 Tahun 2004 tentang Penghapusan Kekerasan Dalam Rumah Tangga (UU. KDRT), Undang-undang Republik Indonesia Nomor 13 Tahun 2006 tentang Perlindungan Saksi dan Korban (UU. PSK), Undang-undang Republik Indonesia Nomor 48 Tahun 2009 tentang Kekuasaan Kehakiman, Undang-undang Republik Indonesia Nomor 16 Tahun 2011 tentang Bantuan Hukum, Undang-undang Republik Indonesia Nomor 23 Tahun 2002 sebagaimana telah diubah dengan Undang-undang Republik Indonesia Nomor 35 Tahun 2014 tentang Perlindungan Anak; 2) Bahan hukum sekunder yang terdiri atas buku-buku yang membicarakan suatu dan / atau beberapa permasalahan hukum, termasuk skripsi, tesis dan desertasi hukum, kamus hukum, jurnal hukum. Hal ini merupakan petunjuk atau penjelasan mengenai bahan hukum primer; ${ }^{10}$ Bahan hukum tersier seperti Kamus Besar Bahasa Indonesia (KBBI) dan ensiklopedia dan internet.

\footnotetext{
${ }^{6}$ Bagir Manan, 2009, Menegakkan Hukum Suatu Pencarian, Asosiasi Advokat Indonesia, Jakarta, hIm. 40.

${ }^{7}$ Peter Mahmud Marzuki, 2007, Penelitian Hukum, Kencana, Jakarta, hlm. 96

${ }^{8}$ Ibid. hlm. 93

${ }_{9}^{9}$ Dyah Octhorina, dan A'an Efendi, 2013, Penelitian Hukum (Legal Research), Sinar Grafika, Jakarta, hlm. 110.

${ }^{10}$ Soerjono Soekanto dalam Zainuddin Ali, 2011, Metode Penelitian Hukum, Cetakan ke-3, Sinar Grafika, Jakarta, hlm.54.
} 
Penyajian penelitan berpangkal pada asas-asas, teori-teori dan doktrin serta perundangundangan yang berlaku. ${ }^{11}$ Spesifikasi penelitian ini adalah bersifat deskriptif sesuai dengan masalah dan tujuan dalam penelitian dengan menggambarkan sejumlah variabel berkenaan dengan masalah yang diteliti.

\section{HAISL PENELITIAN DAN PEMBAHASAN}

\section{Kedudukan Advokat Sebagai Penegak Hukum Dalam Sistem Peradilan Pidana Di Indonesia}

Advokat berasal dari kata advocate, yakni seseorang yang berprofesi sebagai ahli hukum di Pengadilan. Terjemahan lain menyatakan bahwa advocate bermakna sebagai nasihat. Advokat bisa dikatakan penasihat hukum karena pekerjaannya dalam pengadilan sebagai penasihat. ${ }^{12}$

Istilah Penasihat Hukum/Bantuan Hukum dan Advokat/Pengacara merupakan istilah yang tepat dengan fungsinya sebagai pendamping tersangka/terdakwa atau penggugat/tergugat, bila dibandingkan dengan istilah pembela. Karena istilah pembela dapat diartikan sebagai seseorang yang membantu hakim dalam usaha menemukan kebenaran materiil walaupun itu bertolak dari sudut pandang subjektif yaitu berpihak pada kepentingan tersangka/terdakwa.

Menurut pasal 1 butir (1) UURI. No. 18 tahun 2003 tentang Advokat, disebutkan, Advokat ialah orang yang berprofesi memberi jasa hukum, baik didalam maupun diluar pengadilan yang memenuhi syarat berdasarkan ketentuan Undang-undang. Syarat-syarat tersebut tertuang dalam pasal 2 ayat (1) UU. Advokat, yakni "Yang dapat diangkat sebagai Advokat adalah sarjana yang berlatarbelakang pendidikan tinggi hukum dan telah mengikuti pendidikan khusus profesi Advokat yang dilaksanakan Organisasi Advokat". ${ }^{13}$

Pengacara adalah orang yang mengatur dan mengurus tahap-tahapan acara hukum, sejak awal dimulainya kasus perkara sampai dengan selesai pelaksanaan putusan hakim dengan eksekusi. ${ }^{14}$ Sedangkan konsultan hukum yaitu seseorang yang tidak harus memiliki ijin praktek sebagai Advokat atau Pengacara, tetapi ia harus mempunyai pengetahuan yang cukup tentang penyelesaian sengketa di bidang hukum. Namun pada dasarnya fungsi, peran, dan tanggungjawab dari Advokat, Pengacara, Penasehat Hukum adalah sama.

Masyarakat sebagai subjek hukum membutuhkan Advokat untuk membantu menegakkan keadilan. Sasaran menghadirkan Advokat adalah memberikan bantuan hukum bagi terdakwa serta membantu hakim dalam menemukan kebenaran. Sehingga Advokat dianggap sebagai penegak hukum.

Istilah Advokat sesunguhnya telah dikenal semenjak zaman Romawi yang jabatannya disebut officium nobile (profesi yang mulia) ${ }^{15}$ karena mengabdikan dirinya pada kepentingan masyarakat, serta kewajibannya untuk menegakkan hak-hak asasi manusia, menolong orang-orang tanpa honorarium.

Pada zaman Hindia Belanda, menurut Hooggerechshof dan Raadvan justitie para pihak yang berperkara diwajibkan untuk diwakilkan oleh seorang procureur (ahli hukum). Namun berbeda dengannya, untuk golongan Eropa maka Landraad sebagai wadah pengadilan orang pribumi asli tidak mengharuskan perwakilan dalam sidang dimuka pengadilan.

\footnotetext{
${ }^{11}$ Salim HS dan Erlies Septiana Nurbani, 2013, Penerapan Teori Hukum pada Penelitian Tesis dan Disertasi, Raja Grafindo Persada, Jakarta, hlm.12.

${ }^{12}$ Sukris Sarmadi, 2009, Advokat (Litigasi dan Non Litigasi Pengadilan), Mandar Maju, Bandung, hlm. 1.

${ }^{13}$ Supriadi, 2006, Etika dan Tanggung Jawab Profesi Hukum di Indonesia, Sinar Grafika, Jakarta, hlm. 59.

${ }^{14}$ Nikolas Simanjuntak, 2012, Acara Pidana Indonesia dalam Sirkus Hukum, Ghalia, Bogor Indonesia, hlm 134

${ }^{15}$ Ari Yusuf Amir, 2010, Strategi Bisnis Jasa Advokat, cetakan III, Navila Idea, Yogyakarta, hlm. 7
} 
Kemudian pada zaman Bala tentara Jepang, Raadvan justitie dan Residentiegerecht tidak lagi diberlakukan dan di hapus. Baik pribumi maupun Eropa berlaku Tihoo Hooin dan Kotoo Hooin. Seesorang diperbolehkan secara bebas untuk beracara di muka Pengadilan tanpa wakil ahli hukum atau Pengacara atau Advokat. ${ }^{16}$

Pada dasarnya eksistensi Advokat dan pengaturanya di Indonesia telah ada pada sekitar satu setengah abad yang lalu. Namun pengakuan terhadap Advokat tidak diatur dalam suatu peraturan seperti halnya Undang-undang namun hanya tertuang secara sporadis pada pasal-pasal peraturan perundang-undangan yang dikeluarkan sejak masa pemerintah kolonial Belanda.

Peraturan perundang-undangan yang mengatur institusi Advokat sampai saat dibentuknya Undang-undang Nomor 18 Tahun 2003 Tentang Advokat ini masih berdasarkan pada peraturan perundang-undangan peninggalan zaman kolonial, seperti ditemukan dalam :

1. Reglement op de Rechterlijke Organisatie en het Beleid der Justitie in Indonesie (Stb. 1847 : 23 jo. Stb. 1848 : 57), Pasal 185 sampai Pasal 192 dengan segala perubahan dan penambahannya, kemudian;

2. Bepalingen betreffende het kostuum der Rechterlijke Ambtenaren dat der Advokaten, procureurs en Deuwaarders (Stb. 1848 : 8),

3. Bevoegdheid departement hoofd in burgelijke zaken van land (Stb. $1910: 446$ jo. Stb. 1922 : 523), dan

4. Vertegenwoordiging van de land in rechten (K.B.S 1922 : 522).

Untuk menggantikan peraturan perundang-undangan yang diskriminatif dan yang sudah tidak sesuai lagi dengan sistem ketatanegaraan yang berlaku, serta sekaligus untuk memberi landasan yang kokoh pelaksanaan tugas pengabdian Advokat dalam kehidupan masyarakat, maka dibentuk UndangUndang Nomor 18 Tahun 2003 Tentang Advokat sebagaimana diamanatkan dalam Pasal 38 UndangUndang Nomor 14 Tahun 1970 tentang Ketentuan-ketentuan Pokok Kekuasaan Kehakiman, sebagaimana diubah dengan Undang-Undang Nomor 35 Tahun 1999.

Setelah diundangkannya UU No. 18 tahun 2003, Lembaran Negara Republik Indonesia tahun 2003 Nomor 49, tambahan Lembaran Negara Republik Indonesia Nomor 4228 maka istilah Advokat telah menjadi baku dan status Advokat telah mendapat pengakuan sebagai penegak hukum sehingga dikenal catur wangsa (Polisi, Jaksa, Hakim, dan Advokat). Advokat mempunyai kedudukan yang sama dengan penegak hukum lainnya, dan satu-satunya penegak hukum yang bebas dan mandiri yang dijamin oleh hukum serta wilayah kerjanya meliputi seluruh wilayah negara RI. $^{17}$

\section{Kedudukan Advokat Sebagai Penegak Hukum Dalam Sistem Peradilan Pidana Di Indonesia.}

Dalam praktek penegakan hukum di Indonesia, seringkali para penegak hukum sudah menjalankan tugasnya sesuai dengan aturan main yang ada, dalam artian aturan main yang formal. ${ }^{18}$ Seorang Advokat adalah seorang yang berprofesi memberi jasa hukum, baik di dalam maupun di luar pengadilan yang memenuhi persyaratan berdasar ketentuan undang-undang

Kedudukan Advokat sebagai penegak hukum telah diatur didalam Pasal 5 Ayat (1) UURI. No. 18 Tahun 2003 tentang Advokat, yakni, "Advokat berstatus sebagai penegak hukum, bebas dan mandiri yang dijamin oleh hukum dan peraturan perudang-undangan". Lebih lanjut dalam penjelasan pasal 5 ayat (1) UU Advokat, dijelaskan bahwa yang dimaksud dengan "Advokat berstatus sebagai penegak hukum" adalah : "Advokat sebagai salah satu perangkat dalam proses peradilan yang mempunyai

\footnotetext{
${ }^{16}$ Sukris sarmadi, Op. Cit, hlm. 12-19.

${ }^{17}$ Ishaq, 2012, Pendidikan Keadvokatan, Sinar Grafika, Jakarta, hlm. 2.

${ }^{18}$ Bambang Sutiyoso, 2010, Refarmasi Keadilan dan Penegakan Hukum di Indonesia, UII Press, Yogyakarta, hlm. 4.
} 
kedudukan yang setara dengan penegak hukum lainnya dalam menegakkan hukum dan keadilan". Sedangkan yang dimaksud dengan "bebas" adalah sebagaimana dirumuskan dalam penjelasan Pasal 14, yang dimaksud dengan "bebas" adalah tanpa tekanan, ancaman, hambatan, tanpa rasa takut, atau perlakuan yang merendahkan harkat martabat profesi. Kebebasan tersebut dilaksanakan sesuai dengan kode etik profesi dan peraturan perundang-undangan

Penempatan Advokat sebagai sub sistem dalam sistem peradilan pidana sejajar dengan subsistem yang lain (Kepolisian, Kejaksaan, Pengadilan dan Lembaga Pemasyarakatan) merupakan langkah maju dan sangat penting artinya bukan saja bagi pencari keadilan (Justisiabel), tetapi juga demi kepentingan kelancaran proses itu sendiri. Sebagai konsekuensi logis dari pemikiran ini adalah para Advokat harus diberi peluang yang cukup baik melalui pengaturan maupun dalam praktek pemberian Bantuan Hukum untuk akses secara penuh dalam proses peradilan pidana. ${ }^{19}$

. Kedudukan Advokat sebagai penegak hukum, memerlukan suatu organisasi yang merupakan satu-satunya wadah profesi Advokat sebagaimana Pasal 28 Ayat (1) UU Advokat, yaitu "Organisasi Advokat merupakan satu-satunya wadah profesi Advokat yang bebas dan mandiri yang dibentuk sesuai dengan ketentuan Undang-Undang ini dengan maksud dan tujuan untuk meningkatkan kualitas profesi Advokat". Organisasi Advokat, yaitu PERADI, pada dasarnya adalah organ negara dalam arti luas yang bersifat mandiri (independent state organ) yang juga melaksanakan fungsi Negara. ${ }^{20}$

Secara akademis dan (praktis) ternyata masih ada perbedaan pandangan terhadap kedudukan Advokat sebagai penegak hukum dalam sistem peradilan pidana. Ada yang menyebut hanya Kepolisian, Kejaksaan, Pengadilan dan Lembaga Pemasyarakatan. Di pihak lain ada yang menyatakan bahwa Penasihat Hukum juga bisa ditambahkan sebagai bagian dari sub sistem peradilan pidana. Secara normatif maupun dalam kenyataan Lembaga Penegak Hukum tidak hanya terdiri dari tiga lingkungan jabatan tersebut di atas, bahkan dari perspektif pemecahan masalah dan pembaharuan penegak hukum, kalau hanya disebut tiga lingkungan jabatan tersebut, bukan saja tidak lengkap tetapi misleading yang menyebabkan bias. ${ }^{21}$ Namun sejak diundangkannya UURI No. 18 Tahun 2003 tentang Advokat, telah disebutkan bahwa kedudukan Advokat adalah juga sebagai salah satu penegak hukum, bahkan merupakan satu-satunya penegak hukum yang bebas dan mandiri yang dijamin oleh hukum dan peraturan perundang-undangan sehingga kedudukannya sama dengan penegak hukum lainnya. Hal ini juga telah diakuinya sebutan Catur Wangsa penegak hukum (Hakim, Jaksa, Polisi, dan Advokat). Maka harapan yang kemudian muncul dengan diundangkannya UURI. No. 18 Tahun 2003 adalah menjadikan eksistensi Advokat menjadi diakui dan tidak lagi dipandang sebelah mata sehingga dalam menjalankan kewajibannya berkaitan dengan profesinya, seorang Advokat dapat melaksanakannya dengan baik, tanpa tekanan, dan bisa memperjuangkan keadilan menurut dasar dasar hukum yang baik sesuai prosedur beracara di dalam maupun di luar persidangan. Karenanya, sejak klien datang dan kemudian melakukan konsultasi hukum kepada Advokat, maka Advokat tersebut sudah melakukan jasa hukum.

Mengenai bantuan hukum adalah berbeda dengan jasa hukum. Perbedaan ini dilihat dari segi hak dan kewajiban yang melekat antara Advokat dan klien. Memang pada dasarnya hak dan kewajiban antara Advokat dan kliennya adalah sama berkaitan dengan jasa hukum dan bantuan hukum. Dalam jasa hukum seorang Advokat berhak menentukan besar/nilai dari jasa yang akan diberikannya, namun

\footnotetext{
${ }^{19}$ Muhammad Rusli, 2011, Sistem Peradilan Pidana Terpadu, UII Press, Yogyakarta, hlm. 58.

${ }^{20}$ Lihat Pertimbangan Hukum Putusan MK Nomor 014/PUU-IV/2006 mengenai Pengujian Undang-Undang Advokat.

${ }^{21}$ Bagir Manan, Kedudukan Penegak hukum dalam sistem ketatanegaraan Republik Indonesia, Varia Peradilan ke XXI No.243 Februari 2006, hlm. 7
} 
bantuan hukum adalah jasa yang diberikan secara Cuma-cuma. Artinya, tidak ada kewajiban bagi klien untuk membayar sejumlah biaya (lawyer fee, success fee, dll). Dan ini hanya dikenakan kepada klien yang tidak mampu (Pasal 1 angka 9) dimana ketidakmampuan ini bisa dibuktikan dengan surat keterangan yang dikeluarkan oleh pihak yang berwenang.

Pasal 24 Ayat (1) UUD 1945 menyatakan bahwa kekuasaan kehakiman merupakan kekuasaan yang merdeka untuk menyelenggarakan peradilan guna menegakkan hukum dan keadilan. Oleh karena itu, selain pelaku kekuasaan kehakiman, yaitu Mahkamah Agung dan Mahkamah Konstitusi, badan-ban lain yang fungsinya berkaitan dengan kekuasaan kehakiman juga harus mendukung terlaksananya kekuasaan kehakiman yang merdeka. Salah satunya adalah profesi Advokat yang bebas, mandiri, dan bertanggungjawab, sebagaimana selanjutnya diatur dalam Undang-Undang Nomor 18 Tahun 2003.

Kedudukan Advokat dalam sistem penegakan hukum sebagai penegak hukum. Dalam menjalankan fungsi dan tugasnya Advokat seharusnya dilengkapi oleh kewenangan sama halnya dengan penegak hukum lain seperti Polisi, Jaksa Dan Hakim. Ini bermakna bahwa dalam menjalankan tugasnya Advokat tunduk dan patuh pada hukum dan perundang-undangan. Namun apakah makna 'penegak hukum' bagi Advokat sama dengan penegak hukum bagi Polisi, Jaksa, Dan Hakim? Pasal 5 ayat (1) UU Advokat tak merinci lebih jelas kewenangan Advokat sebagai penegak hukum. Memang ada semacam kontradiksi dalam status itu, karena di satu sisi harus membela kepentingan klien, tapi di sisi lain menyandang predikat penegak hukum. Konsekuensinya, Advokat tidak boleh membela kepentingan klien secara membabi buta karena juga harus ikut menegakkan hukum.

Kewenangan Advokat timbul setelah Advokat mendapatkan kuasa dan klien yakni kewenangan dalam menjalankan profesinya sebagai penegak hukum. Organisasi Advokat pada dasarnya organ dalam arti yang luas dan bersifat mandiri yang juga melaksanakan fungsi negara. Pasal 5 ayat (1) UU Advokat mengenai status Advokat sebagai penegak hukum seharusnya dirinci dan diarahkan untuk memperkuat kewenangan Advokat. Termasuk memberi kemungkinan langkah hukum bagi Advokat terhadap penegak hukum lain yang melanggar hukum dan perundang-undangan.

Dengan demikian, profesi Advokat memiliki peran penting dalam upaya penegakan hukum. Setiap proses hukum, baik pidana, perdata, tata usaha negara, selalu melibatkan profesi advokat yang kedudukannya setara dengan penegak hukum lainnya. Kewenangan Advokat dalam sistem penegakan hukum menjadi sangat penting guna mengjaga keindependensian Advokat dalam menjalanakan profesinya dan juga menghindari adanya kesewenang-wenangan yang dilakukan oleh penegak hukum yang lain. Kemandirian dan kebebasan yang dimiliki oleh profesi Advokat, tentu harus diikuti oleh adanya tanggungjawab masing-masing Advokat dan Organisasi Profesi Advokat.

\section{Peran Advokat Sebagai Penegak Hukum Dalam Mendukung Terwujudnya Sistem Peradilan Pidana Terpadu Dalam Penegakan Hukum Pidana Di Indonesia.}

Peran menurut "Kamus Besar Bahasa Indonesia"22 mempunyai arti pemain sandiwara (film), tukang lawak pada permainan makyong, perangkat tingkah yang diharapkan dimiliki oleh orang yang berkedudukan di masyarakat. Ketika istilah peran digunakan dalam lingkungan pekerjaan, maka seseorang yang diberi (atau mendapatkan) sesuatu posisi, juga diharapkan menjalankan perannya sesuai dengan apa yang diharapkan oleh pekerjaan tersebut. Dengan demikian yang dimaksud dengan Peran dalam penelitian ini adalah tindakan atau perbuatan yang dilakukan oleh Advokat sebagai penegak hukum dalam rangka mendukung terwujudnya sistem peradilan pidana terpadu dalam

\footnotetext{
${ }^{22}$ Kamus Besar Bahasa Indonesia, Pusat Bahasa, PT Gramedia Pustaka Utama
} 
penegakan hukum pidana di Indonesia.

Hadirnya UURI. No. 8 Tahun 1981 tentang KUHAP, UURI No. 18 Tahun 2003 tentang Advokat, UURI. No. 48 Tahun 2009 tentang Kekuasaan Kehakiman serta UURI No.16 Tahun 2011 tentang Bantuan Hukum, secara yuridis normatif, dikonstruksikan sebagai bagian dari adanya peran Advokat dalam sistem peradilan pidana dengan harapan dapat dilaksanakan secara konsekuen, sehingga kebutuhan akan jasa hukum / bantuan hukum disamping demi kepentingan mereka yang terlibat suatu perkara (tersangka / terdakwa) juga untuk kepentingan sistem peradilan pidana itu sendiri yaitu dalam rangka membantu mencari kebenaran meteriil atas suatu perkara pidana. mendapatkan kebenaran materiil adalah suatu tujuan yang harus dicapai oleh hukum acara pidana, yang pelaksanaanya dilakukan dengan sistem peradilan pidana.

Sistem Peradilan Pidana adalah suatu komponen (sub system) peradilan pidana yang saling terkait atau tergantung satu sama lain dan bekerja untuk satu tujuan, yaitu untuk menanggulangi kejahatan sampai batas yang dapat ditoleransi masyarakat. Pengertian itu menggambarkan adanya keterpaduan antara sub-sub system yang ada dalam peradilan. Sedangkan kata terpadu dalam sistem peradilan terpadu disini adalah adanya kesamaaan prosedur (sub sistem dalam peradilan pidana pada posisi masing-masing harus mengikuti aturan-aturan yang telah ditetapkan/ ditentukan di dalam undang-undang), persepsi (adanya pemahaman/ pengetahuan yang sama antara sub-sub system terhadap perkara/ kasus yang ada), dan tujuan (sub-sub sistem peradilan harus memiliki tujuan sama yaitu menanggulangi kejahatan hingga batas toleransi yang dapat diterima masyarakat). ${ }^{23}$ Sistem Peradilan Pidana Terpadu adalah sistem peradilan pidana yang didukung oleh pengaturan jasa hukum dan hak bantuan hukum yang memungkinkan komponen Advokat mampu secara penuh dalam proses peradilan pidana. perkataan "terpadu" disini dimaksudkan untuk memberi tekanan pada aspek koordinasi dan kerja sama antar komponen dalam sistem peradilan pidana terpadu dimana komponen Advokat ada di dalamnya. ${ }^{24}$

Untuk menuju Sistem Peradilan Pidana Terpadu maka diperlukanlah seorang Advokat profesional, bukan seorang Advokat "asal-asalan". Dalam UURI. No.18 tahun 2003 tentang Advokat telah diatur jelas dengan dilengkapi peraturan-peraturan lainnya tentang kualifikasi dan persyaratanpersyaratan yang ketat untuk seseorang dapat diangkat menjadi seorang Advokat.

Profesi Advokat disini termasuk ke dalam golongan Lembaga Penegak Hukum non pro justitia di luar pemerintahan yang juga berperan penting dalam dan menentukan pelaksanaan dan wajah penegakan hukum meskipun belum menjadi sub sistem dari sistem peradilan pidana. Jasa hukum / bantuan hukum oleh Advokat sangat erat kaitannya dengan usaha pencari keadilan. Hak untuk mendapatkan bantuan hukum sebagai salah satu hak asasi manusia sangat didambakan oleh semua orang yang tersangkut suatu perkara. Dalam hukum positif Indonesia ketentuan mengenai jasa hukum / bantuan hukum ini diketemukan antara lain dalam UU No.16 Tahun 2011 tentang Bantuan Hukum, Undang-undang No. 48 Tahun 2009 Tentang Kekuasaan Kehakiman, UURI No. 18 Tahun 2003 Tentang Advokat dan juga terdapat dalam Undang-undang No. 8 Tahun 1981 Tentang KUHAP yaitu pasal-pasal sebagai berikut:

1. Bab VI Tentang tersangka atau terdakwa, pasal 54-57; Pasal 60-62.

2. Bab VII Tentang bantuan hukum, pasal 69-74

3. Bab XIV tentang Penyidikan, yaitu pasal 114 dan 115.

Ketentuan tersebut di atas bisa dikatakan sebagai perwujudan dan penjabaran lebih lanjut dari

\footnotetext{
${ }^{23}$ Muhammad Rusli, 2011, Sistem Peradilan Pidana Indonesia, UII Press, Yogyakarta, hlm. 80.

${ }^{24}$ Muhammad Rusli, Op.Cit.
} 
asas persamaan di muka hukum (equality before the law) seperti yang tersirat dalam Pasal 27 ayat 1 UUD 1945.

Mengenai bantuan hukum, bentuk dan jenis umum bantuan hukum, yakni perwakilan profesional secara gratis yang dilakukan Advokat tunjukkan pengadilan, dianggap sebagai koreksi terhadap distribusi sumber daya hukum yang timpang antara orang yang berada dan orang miskin. Terutama bila lingkupnya dibatasi pada tuntutan pidana, bantuan hukum merupakan tanggapan minimal, sebagai pemantas, terhadap kegagalan mitos bahwa semua orang sama di mata hukum. Bantuan Hukum dikonsepsikan sebagai:

1. Suatu hak yang dapat dituntut oleh setiap subjek hukum bilamana ia memerlukannya dan pemenuhannya merupakan kewajiban;

2. Bantuan hukum merupakan pekerjaan profesional yang memerlukan pendidikan dan keahlian khusus;

3. Bantuan hukum adalah merupakan suatu pekerjaan pemberian jasa hukum dari seorang ahli hukum kepada mereka yang membutuhkan.

Namun demikian, seiring berjalannya proses perubahan sosial, faktor-faktor yang mempengaruhi terhadap bekerjanya hukum dalam masyarakat bukan hanya faktor internal dalam sistem hukum itu sendiri (hukum, aparat, organisasi dan fasilitas), tapi juga faktor-faktor eksternal diluar sistem hukum, seperti sistem sosial, politik, ekonomi dan budaya. Bahkan dalam era globalisasi sekarang ini, pengaruh faktor tata pergaulan Internasional tidak dapat diabaikan. ${ }^{25}$ Pemikiran untuk memaksimalkan peran Advokat dalam proses peradilan pidana, tampaknya merupakan pemikiran yang realistis, sebab dalam praktek pemberian jasa hukum / bantuan hukum ternyata masih ditemui banyak hambatan bersifat politis, sosial, ekonomi/finansial dan psikologis.

Para Legal Profesional seperti Advokat memiliki prilaku yang tidak selalu sama di muka pengadilan. Marc Galanter membedakan Advokat yang tergolong "one-shooter" dan "repeat players" yang pertama bersifat amateuran sedang yang kedua bersifat profesional. Keduanya memiliki perbedaan bertalian dengan cara-cara kerja, intensitas hubungan dengan pengadilan serta jenis perkara yang ditanganinya. Hanya Advokat profesional yang setiap mendampingi klien, memiliki intelegensi yang tinggi, keahlian dan spesialisasi, hubungan pribadi yang luas dengan berbagai instansi, berpegang pada kode etik profesi, kredibilitas serta reputasi, bekerja secara optimal dengan sedikit kerugian serta kemampuan litigasi yang baik. Sehingga stigma buruk terhadap profesi Advokat yang disebabkan oleh beberapa oknum yang menyimpang dari kode etik profesi Advokat atau bahkan perbedaan pandang dari aspek kultural seperti pandangan sinis / negatif terhadap para pemberi jasa bantuan hukum ini dapat diminimalisir dengan cara menunjukkan profesionalitas para Advokat dalam menjalankan profesinya serta kesadaran hukum masyarakat akan hukum dan meningkatkan pemahaman masyarakat terhadap profesi Advokat sebagai penolong masyarakat dalam menegakkan kebenaran dan keadilan.

Dengan besarnya peranan profesi Advokat yang profesional menjadi sebuah komponen dalam sistem peradilan pidana terpadu dimana adanya koordinasi dan kerja sama antar komponen, maka perlunya perombakan ulang terhadap peraturan perundang-undangan yang terkait dengan sistem peradilan pidana, agar semakin memperkokoh posisi kedudukan Advokat sebagai sub sistem dari sistem peradilan pidana itu sendiri, sehingga menjadi sub sistem yang sejajar dengan subsistem yang lain (Kepolisian, Kejaksaan, Pengadilan dan Lembaga Pemasyarakatan). Tidak seperti saat ini, tanpa Advokat pun proses penegakan dalam sistem peradilan pidana itu tetap berjalan sehingga dominasi penguasaan hukum dalam penegakan hukum seolah menjadi milik para penegak hukum yang berada

\footnotetext{
${ }^{25}$ Bambang Sutiyoso, 2010, Refarmasi Keadilan dan Penegakan Hukum di Indonesia, UII Press, Yogyakarta, hlm. 111.
} 
didalam pemerintahan.

Pelaksanaan hukum dalam masyarakat sangat bergantung pada kesadaran hukum masyarakat karena ia menjadi subjek hukum. Namun juga sangat ditentukan oleh pelaksanaan penegakan hukum oleh para petugas penegak hukum. Banyak peraturan hukum tidak dapat terlaksana dengan baik karena oknum penegak hukum kurang paham tugas dan tanggungjawabnya.

\section{Tugas Dan Wewenang Serta Hak Dan Kewajiban Advokat}

Kewenangan dan kekuatan Advokat sebagai kuasa hukum dari klien bergantung pada ada atau tidaknya surat kuasa yang dilimpahkan padanya. Dalam lapangan hukum perdata, Advokat bertindak sebagai wakil dari klien secara litigasi di Pengadilan perdata dimulai sejak pendaftaran perkara ke kepaniteraan sampai pada sidang dimuka pengadilan. Begitu pula dalam lapangan hukum pidana, Advokat bertindak sebagai wakil klien mulai dari tingkat pemeriksaan, penyidikan hingga di muka sidang pengadilan. ${ }^{26}$

Advokat mempunyai prinsip kerja yang kemudian disebut dan direduksi menjadi kode etik profesi Advokat sebagai dasar pijakan seorang Advokat dalam menjalankan aktifitasnya sebagai penasihat hukum, kuasa hukum maupun penegak hukum sesuai dengan yang disebutkan dalam pasal 26 UU No. 18 Tahun 2003 bahwa:.27 "Untuk menjaga martabat dan kehormatan profesi Advokat disusun kode etik profesi Advokat dan organisasi Advokat. Maka Advokat wajib tunduk dan mematuhi kode etik profesi Advokat dan ketentuan tentang Dewan Kehormatan Organisasi Advokat".Adapun kode etik yang berhubungan dengan cara kerja Advokat khususnya dalam menangani perkara seorang Advokat harus memegang rahasia yang berkaitan dengan rahasia jabatan yang melekat pada dirinya. ${ }^{28}$ Advokat dalam membela kliennya harus memegang teguh prinsip Equality before the Law yakni jaminan kesederajatan dihadapan hukum dan prinsip Presumption of innocene (Praduga tak bersalah).

Adapun tugas dan tanggungjawab yang diemban Advokat dan harus diperhatikan dalam menangani suatu perkara adalah sebagai berikut:

- Menjunjung tinggi kode etik profesinya;

- Membimbing dan melindungi kliennya dari petaka duniawi dan ukhrawi agar dapat menemukan kebenaran dan keadilan yang memuaskan semua pihak, sesuai dengan nilai-nilai hukum, moral dan agama;

- Membantu terciptanya proses peradilan yang sederhana, cepat dan biaya ringan, serta tercapainya penyelesaian perkara secara final;

- Menghormati lembaga peradilan dan proses peradilan sesuai dengan norma hukum, agama, dan moral;

- Melindungi kliennya dari kedzaliman pihak lain dan melindunginya pula dari berbuat dzalim kepada pihak lain;

- Memegang teguh amanah yang diberikan kliennya dengan penuh tanggungjawab baik terhadap kliennya, diri sendiri, hukum dan moral, maupun terhadap Tuhan Yang Maha Esa.

- Memberikan laporan dan penjelasan secara periodik kepada kliennya mengenai tugas yang dipercayakan padanya;

- Menghindarkan diri dari bentuk pemerasan terselubung terhadap kliennya;

- Bersikap simpatik dan turut merasakan apa yang diderita oleh kliennya bahkan mengutamakan kepentingan kliennya daripada pribadinya;

\footnotetext{
${ }^{26}$ Sukris Sarmandi, Op.Cit, hlm. 111-113.

${ }^{27}$ Supriadi, Op.Cit, hlm. 87.

${ }^{28}$ Ishaq, Op.Cit, hlm. 53-56.
} 
- Antara kuasa hukum atau Advokat dengan kliennya haruslah terjalin hubungan saling percaya dan dapat dipercaya sehingga tidak saling merugikan dan dirugikan.

- Melaksanakan tugas profesi sebagai pemberi jasa hukum bertindak jujur, adil, dan bertanggung jawab berdasarkan hukum dan keadilan;

- Advokat juga berkewajiban memberikan bantuan hukum secara cuma-cuma bagi klien yang tidak mampu, hal ini sesuai dengan keputusan Mahkamah Agung No. 5/KMA/1972 tentang yang wajib memberi bantuan hukum.

Advokat / Penasehat Hukum sebagai penegak hukum dapat bertindak mendampingi dan atau mewakili dalam perkara perdata, TUN maupun pidana. Dalam perkara pidana tersangka atau terdakwa berhak mendapat Bantuan Hukum dari seorang atau lebih Penasehat Hukum selama dalam waktu dan pada setiap tingkat pemeriksaan perkara. Untuk mendapatkan Penasehat Hukum, tersangka atau terdakwa berhak memilih sendiri penasehat hukumnya (pasal 54-55 KUHAP). Bagi tersangka / terdakwa yang disangka atau didakwa melakukan tindak pidana yang diancam dengan pidana 5 tahun atau lebih atau pidana mati, yang tidak mampu dan tidak mempunyai Penasehat Hukum sendiri, maka pejabat bersangkutan wajib menunjuk Penasehat Hukum bagi mereka yang memberikan bantuan hukum dengan cuma-cuma (pasal 56 KUHAP). Penasehat Hukum berhak menghubungi tersangka sejak saat ia ditangkap atau ditahan pada semua tingkat pemeriksaan. Untuk kepentingan pembelaan, Penasehat Hukum setiap saat dapat menghubungi dan berbicara dengan tersangka (pasal 69-70 KUHAP). Penasehat Hukum dapat meminta turunan Berita Acara Pemeriksaan (BAP) kepada pejabat bersangkutan (pasal 72 KUHAP). Penasehat hukum tidak boleh dikurangi kebebasannya dalam berhubungan dengan tersangka (pasal 74 KUHAP). ${ }^{29}$

\begin{tabular}{|c|c|c|c|}
\hline \multicolumn{4}{|c|}{ TUGAS DAN WEWENANG ADVOKAT } \\
\hline $\begin{array}{l}\text { UURI No. } 8 \text { Tahun } 1981 \\
\text { Tentang Hukum Acara } \\
\text { Pidana (KUHAP) }\end{array}$ & $\begin{array}{l}\text { UURI No. } 18 \text { Tahun } 2003 \\
\text { Tentang Advokat }\end{array}$ & $\begin{array}{c}\text { UURI No. } 48 \\
\text { Tahun } 2009 \\
\text { Tentang } \\
\text { Kekuasaan } \\
\text { Kehakiman } \\
\end{array}$ & $\begin{array}{l}\text { UURI No. } 16 \text { Tahun } \\
2001 \text { Tentang } \\
\text { Bantuan Hukum }\end{array}$ \\
\hline $\begin{array}{l}\text { Memberikan bantuan } \\
\text { hukum kepada tersangka } \\
\text { atau terdakwa selama } \\
\text { dalam waktu dan pada } \\
\text { tingkat pemeriksaan. }\end{array}$ & $\begin{array}{c}\text { Memberi jasa } \\
\text { pelayanan hukum }\end{array}$ & $\begin{array}{c}\text { Pemberian } \\
\text { bantuan hukum } \\
\text { kepada pencari } \\
\text { keadilan yang } \\
\text { tidak ampu. } \\
\end{array}$ & $\begin{array}{c}\text { Melakukan } \\
\text { pelayanan } \\
\text { bantuan hukum }\end{array}$ \\
\hline Pasal 54 & Pasal 1 butir 2 & Ps. 56 ayat (1) & Pasal 9 huruf $d$ \\
\hline $\begin{array}{l}\text { Dalam hal tersangka atau } \\
\text { terdakwa disangka atau } \\
\text { didakwa melakukan tindak } \\
\text { pidana yang diancam } \\
\text { dengan pidana mati atau } \\
\text { ancaman pidana lima belas } \\
\text { tahun atau lebih yang tidak } \\
\text { mempunyai penasihat } \\
\text { hukum sendiri pejabat }\end{array}$ & $\begin{array}{l}\text { Memberikan bantuan } \\
\text { hukum secara cuma-cuma } \\
\text { kepada pencari keadilan } \\
\text { yang tidak mampu. }\end{array}$ & & \\
\hline
\end{tabular}

${ }^{29}$ Hilman Hadikusuma, 2013, Bahasa Hukum Indonesia, PT Alumni, Bandung hlm.184-185. 


\begin{tabular}{|c|c|c|c|}
\hline $\begin{array}{c}\text { yang bersangkutan } \\
\text { pada semua tingkat } \\
\text { pemeriksaan dalam proses } \\
\text { peradilan wajib menunjuk } \\
\text { penasehat hukum. }\end{array}$ & & & \\
\hline pasal 56 ayat (1) & Pasal 22 ayat (1) & & \\
\hline & $\begin{array}{l}\text { Merahasiakan segala } \\
\text { sesuatu yang diketahui } \\
\text { atau diperoleh dari } \\
\text { kliennya karena adanya } \\
\text { hubungan profesi. }\end{array}$ & & $\begin{array}{c}\text { Menyelenggarakan } \\
\text { konsultasi hukum, } \\
\text { penyuluhan hukum } \\
\text { dan kegiatan lain } \\
\text { yang berkaitan } \\
\text { dengan bantuan } \\
\text { hukum }\end{array}$ \\
\hline & Pasal 19 ayat (1) & & Pasal 9 huruf c \\
\hline \multicolumn{4}{|c|}{ HAK HAK ADVOKAT } \\
\hline $\begin{array}{l}\text { UURI No. } 8 \text { Tahun } 1981 \\
\text { Tentang Hukum Acara } \\
\text { Pidana (KUHAP) }\end{array}$ & $\begin{array}{l}\text { UURI No. } 18 \text { Tahun } 2003 \\
\text { Tentang Advokat }\end{array}$ & $\begin{array}{c}\text { UURI No. } 48 \\
\text { Tahun } 2009 \\
\text { Tentang } \\
\text { Kekuasaan } \\
\text { Kehakiman } \\
\end{array}$ & $\begin{array}{l}\text { UURI No. } 16 \text { Tahun } \\
2001 \text { Tentang } \\
\text { Bantuan Hukum }\end{array}$ \\
\hline $\begin{array}{l}\text { Menghubungi tersangka } \\
\text { sejak Saat ditangkap atau } \\
\text { ditahan Pada semua } \\
\text { tingkat pemeriksaan. }\end{array}$ & $\begin{array}{c}\text { Bebas mengeluarkan } \\
\text { pendapat atau } \\
\text { pernyataan dalam } \\
\text { membela perkara di } \\
\text { dalam sidang pengadilan } \\
\text { dengan berpegang teguh } \\
\text { pada kode etik profesi } \\
\text { dan peraturan } \\
\text { perundang-udangan }\end{array}$ & & $\begin{array}{c}\text { Mengeluarkan } \\
\text { pendapat atau } \\
\text { pernyataan dalam } \\
\text { membela perkara }\end{array}$ \\
\hline Pasal 69 & Pasal 14 & & Pasal 9 huruf (e) \\
\hline $\begin{array}{l}\text { Menghubungi dan } \\
\text { berbicara dengan } \\
\text { tersangka pada setiap } \\
\text { tingkat pemeriksaan dan } \\
\text { setiap waktu untuk } \\
\text { kepentingan pembelaan } \\
\text { perkaranya }\end{array}$ & $\begin{array}{l}\text { Memperoleh informasi, } \\
\text { data, dan dokumen } \\
\text { lainnya, baik dari instansi } \\
\text { pemerintah maupun } \\
\text { pihak lain yang berkaitan } \\
\text { guna pembelaan } \\
\text { kepentingan klien sesuai } \\
\text { dengan peraturan } \\
\text { perundang-undangan. }\end{array}$ & & $\begin{array}{l}\text { Mendapatkan } \\
\text { informasi dari } \\
\text { instansi pemerintah } \\
\text { guna pembelaan }\end{array}$ \\
\hline Pasal 70 ayat (1) & Pasal 17 & & Pasal 9 huruf (f ) \\
\hline \multicolumn{4}{|l|}{$\begin{array}{l}\text { Menerima "turunan Berita } \\
\text { Acara Pemeriksaan" }\end{array}$} \\
\hline \multicolumn{4}{|l|}{ Pasal 72} \\
\hline $\begin{array}{l}\text { Mengirim dan menerima } \\
\text { surat dari tersangka setiap }\end{array}$ & & & \\
\hline
\end{tabular}




\begin{tabular}{|c|c|c|c|}
\hline kali dikehendaki olehnya. & & & \\
\hline \multicolumn{4}{|l|}{ Pasal 73} \\
\hline \multicolumn{4}{|l|}{$\begin{array}{l}\text { Tidak boleh dikurangi } \\
\text { kebebasannya dalam } \\
\text { berhubungan dengan } \\
\text { tersangka }\end{array}$} \\
\hline \multicolumn{4}{|l|}{ Pasal 74} \\
\hline $\begin{array}{c}\text { Mengikuti jalannya } \\
\text { pemeriksaan dengan jalan } \\
\text { melihat tetapi tidak dapat } \\
\text { mendengar pemeriksaan } \\
\text { terhadap tersangka }\end{array}$ & $\begin{array}{c}\text { Tidak dapat dituntut } \\
\text { secara pidana atau } \\
\text { perdata dalam membela } \\
\text { perkara }\end{array}$ & & \\
\hline \multirow[t]{5}{*}{ Pasal 115 ayat (1) } & Pasal 16 & & \\
\hline & & $\begin{array}{l}\text { Badan yang } \\
\text { fungsinya } \\
\text { berkaitan } \\
\text { dengan } \\
\text { kekuasan } \\
\text { kehakiman. }\end{array}$ & \\
\hline & & Ps. 38 ayat (1) & \\
\hline & & & $\begin{array}{c}\text { Mendapatkan } \\
\text { jaminan } \\
\text { keselamatan, } \\
\text { kemanan dan } \\
\text { perlindungan hukum } \\
\text { selama memberi } \\
\text { bantuan hukum }\end{array}$ \\
\hline & & & Pasal 9 huruf g \\
\hline
\end{tabular}

\section{Peran Advokat Sebagai Penegak Hukum Dalam Mendukung Terwujudnya Sistem Peradilan Pidana Terpadu Dalam Penegakan Hukum Pidana Di Indonesia}

Jika dipandang dari segi bentuk dan tempatnya, maka peran Advokat sebagai penegak hukum dalam mendukung terwujudnya sistem peradilan pidana terpadu dalam penegakan hukum pidana di Indonesia, terdapat 2 (dua) peran utama yakni :

1. Peran Advokat dalam bentuk pendampingan hukum terhadap pelaku yang diatur didalam KUHAP, yakni :

- Pendampingan hukum oleh Advokat terhadap pelaku yang diatur dalam Undang-undang Republik Indonesia Nomor 8 Tahun 1981 Tentang Hukum Acara Pidana (KUHAP). Didalam KUHAP ternyata memang tidak mengatur mengenai peran Advokat dalam pendampingan hukum terhadap korban oleh Advokat. Adapun yang diatur didalam KUHAP adalah peran Advokat dalam pendampingan hukum terhadap tersangka atau terdakwa selama dalam waktu dan pada setiap tingkat pemeriksaan (Pasal 54 KUHAP). Menurut Yahya Harahap, ${ }^{30}$ kedudukan

\footnotetext{
${ }^{30}$ Yahya Harahap. 2016, Pembahasan Permasalahan dan Penerapan KUHAP, Penyidikan dan Penuntutan, Sinar Grafika, Jakarta, hlm. 133-134
} 
dan kehadiran serta manfaat Penasihat Hukum mengikuti jalannya pemeriksaan penyidikan adalah secara pasif. sebagai "penonton". Terbatas hanya melihat serta mendengar atau within sight and within hearing. tidak diperkenankan memberi nasihat. Manfaatnya, paling tidak mencegah penyidik membuat suasana pemeriksaan lebih manusiawi, dan dari segi psikologis, mendorong tersangka, terdakwa (pelaku) lebih berani mengemukakan kebenaran yang dimiliki dan diketahuinya.

2. Peran Advokat dalam bentuk pendampingan hukum terhadap korban yang diatur diluar KUHAP, yakni :

1. Pendampingan hukum oleh Advokat terhadap korban yakni diatur dalam UURI. No. 23 Tahun 2004 tentang Penghapusan Kekerasan Dalam Rumah Tangga (UU KDRT) diatur mengenai peran dan fungsi Advokat dalam mendampingi korban kekerasan dalam rumah tangga (KDRT) dalam pemeriksaan di pengadilan. Dalam Pasal 25 (UU KDRT) disebutkan bahwa dalam hal memberikan perlindungan dan pelayanan, Advokat wajib:

a. Memberikan konsultasi hukum yang mencakup informasi mengenai hak-hak korban dan proses peradilan;

b. Mendampingi korban di tingkat penyidikan, penuntutan, dan pemeriksaan dalam sidang pengadilan dan membantu korban untuk secara lengkap memaparkan kekerasan dalam rumah tangga yang dialaminya; atau

c. Melakukan koordinasi dengan sesama penegak hukum, relawan pendamping, dan pekerja sosial agar proses peradilan berjalan sebagaimana mestinya.

2. Pendampingan hukum oleh Advokat terhadap korban yakni dalam perkara atau kasus yang melibatkan anak-anak di bawah 18 (delapan belas) tahun sebagaimana diatur dalam Pasal 18 UURI. No. 23 Tahun 2002 yang telah diperbaharui dengan UURI. No. 35 Tahun 2014 tentang Perlindungan Anak, diatur bahwa setiap anak yang menjadi korban atau pelaku tindak pidana berhak mendapatkan bantuan hukum dan bantuan lainnya. Pemberian bantuan hukum melibatkan Advokat diperuntukkan bagi anak-anak korban atau pelaku.

3. Pendampingan hukum oleh Advokat terhadap korban yakni diatur dalam UURI. No. 13 Tahun 2006 tentang Perlindungan Saksi dan Korban (UU PSK) hak-hak korban diatur dalam Pasal 5 ayat (1) yang apabila dihubungkan dengan peran Advokat, maka peran Advokat akan terkait dengan hak korban terutama pada Pasal 5 ayat (1):

- huruf f.mendapatkan informasi mengenai perkembangan kasus;

- huruf g.mendapatkan informasi mengenai putusan pengadilan;

- huruf h.mengetahui dalam hal terpidana dibebaskan dan;

- huruf I.mendapat nasihat hukum.

Pada dasarnya peran dan fungsi Advokat yang mendampingi korban dalam pemeriksaan di pengadilan adalah untuk memastikan hak-hak korban terpenuhi sesuai peraturan perundangundangan. 


\begin{tabular}{|c|c|}
\hline \multicolumn{2}{|c|}{$\begin{array}{l}\text { BENTUK DAN TEMPAT PERAN ADVOKAT SEBAGAI } \\
\text { PENEGAK HUKUM DALAM MENDUKUNG TERWUJUDNYA SISTEM PERADILAN PIDANA TERPADU } \\
\text { DALAM PENEGAKAN HUKUM PIDANA DI INDONESIA }\end{array}$} \\
\hline BENTUK & BENTUK \\
\hline Pendampingan Hukum Terhadap Pelaku & Pendampingan Hukum Terha \\
\hline $\begin{array}{l}\text { TEMPAT } \\
\end{array}$ & $\begin{array}{r}\text { TEMPAT } \\
\end{array}$ \\
\hline $\begin{array}{c}\text { Didalam KUHAP } \\
\text { Berdasar Undang-undang Nomor } 8 \text { Tahun } 1981 \\
\text { Tentang Hukum Acara Pidana (KUHAP) }\end{array}$ & Diluar KUHAP \\
\hline \multirow{3}{*}{$\begin{array}{l}\text { Didalam KUHAP ternyata memang tidak } \\
\text { mengatur mengenai peran Advokat dalam } \\
\text { pendampingan hukum terhadap korban oleh } \\
\text { Advokat. Adapun yang diatur didalam KUHAP } \\
\text { adalah peran Advokat dalam pendampingan } \\
\text { hukum terhadap tersangka atau terdakwa selama } \\
\text { dalam waktu dan pada setiap tingkat } \\
\text { pemeriksaan (Pasal } 54 \text { KUHAP), }\end{array}$} & $\begin{array}{l}\text { Undang-undang Republik Indonesia Nomor } 23 \\
\text { Tahun } 2004 \text { tentang Penghapusan Kekerasan } \\
\text { Dalam Rumah Tangga (UU. KDRT) }\end{array}$ \\
\hline & $\begin{array}{l}\text { Undang-undang Republik Indonesia Nomor } 13 \\
\text { Tahun } 2006 \text { tentang Perlindungan Saksi dan } \\
\text { Korban (UU. PSK) }\end{array}$ \\
\hline & $\begin{array}{l}\text { Undang-undang Republik Indonesia Nomor } 23 \\
\text { Tahun } 2002 \text { sebagaimana telah diubah dengan } \\
\text { Undang-undang Republik Indonesia Nomor } 35 \\
\text { Tahun } 2014 \text { tentang Perlindungan Anak. }\end{array}$ \\
\hline
\end{tabular}

Penegakan hukum merupakan rangkaian proses penjabaran nilai, ide, dan cita untuk menjadi sebuah tujuan hukum yakni keadilan dan kebenaran. Nilai-nilai yang terkandung didalamnya haruslah diwujudkan menjadi realitas yang nyata. Eksistensi hukum menjadi nyata jika nilai-nilai moral yang terkandung dalam hukum dapat diimplementasikan dengan baik. ${ }^{31}$ Penegakan hukum pada prinsipnya harus memberikan manfaat atau berdaya guna bagi masyarakat untuk mencapai suatu keadilan.

Berdasar tugas dan wewenang Advokat. ${ }^{32}$ tugas memiliki arti sesuatu yang wajib dikerjakan, sedangkan wewenang memiliki arti kekuasaan untuk memberi perintah ${ }^{33}$, sehingga Advokat memiliki fungsi, antara lain :

a. Advokat sebagai penegak hukum akan menegakkan hukum dan keadilan. Sedang Advokat sebagai profesi hukum akan membela kepentingan klien dengan tidak secara membabi buta, membantu melancarkan penyelesaian perkara dengan membantu hakim dalam memutuskan perkara melalui data dan informasi yang ada untuk disampaikan di pengadilan, sesuai kode etik profesi, menjunjung tinggi Pancasila, hukum dan keadilan..

b. Advokat merupakan pekerjaan yang disebut beroep, yakni pekerjaan profesional yang berdasarkan keahlian di bidang hukum yang diikat oleh aturan tingkah laku dan kode etik profesi. ${ }^{34}$ Pemberian pelayanan jasa hukum oleh Advokat disebut bantuan hukum (legal aid),"legal aid" sendiri memiliki

\footnotetext{
${ }^{31}$ Satjipto Raharjo, 2009, Penegakan Hukum di Indonesia (Suatu Tinjauan Sosiologis), Genta Publishing ,Yogyakarta, hlm. Vii.

${ }^{32}$ W.J.S Poerwadarminta, 2007, Kamus Umum Bahasa Indonesia, Edisi Ketiga Cetakan keempat, Balai Pustaka, Jakarta, hlm. 1299.

${ }^{33}$ Ibid., hlm. 1366.

${ }^{34}$ Bagir Manan, 2009, Menegakkan Hukum Suatu Pencarin, Asosiasi Advokat Indonesia, Jakarta, hlm. 282.
} 
makna Free or inexpensive legal services provided to those who cannot afford to pay full price ${ }^{35}$ Bantuan hukum (Legal aid) dalam arti sempit sebagai pemberian jasa bantuan hukum secara cumacuma kepada pencari keadilan yang tidak mampu. Sedangkan istilah legal assistance, bantuan hukum yang cakupanya luas tidak hanya digunakan untuk pencari keadilan yang tidak mampu, tetapi juga pemberian bantuan hukum Advokat mempergunakan honorarium, ${ }^{36}$

c. Advokat dalam kedudukan sebagai penegak hukum yang berada di luar pemerintahan. Keberadaan Advokat sebagai penyeimbang dominasi penegak hukum tidak hanya sebagai upaya untuk melindungi hak pencari keadilan, namun juga sebagi bentuk perwakilan masyarakat didalam suatu proses peradilan. Keberadaan Advokat dapat mencegah kesewenang-wenangan dari penegak hukum lain seperti Polisi, Jaksa dan Hakim ${ }^{37}$

d. Advokat akan melakukan fungsi berkaitan dengan kekuasaan kehakiman, sejatinya Advokat berperan sekali dalam proses peradilan, suatu proses peradilan tidak akan menjadi efisien dan efektif tanpa adanya Advokat. ${ }^{38}$

e. Advokat akan bertindak untuk membela harkat dan marbatabat manusia didalam proses peradilan pidana termasuk tersangka atau terdakwa yang berhak didampingi Penasehat Hukum, hak diadili secara terbuka untuk umum, hak mengajukan saksi-saksi, melakukan upaya hukum, asas praduga tak bersalah, menghindari error in persona. ${ }^{39}$

\section{PENUTUP}

\section{Kesimpulan}

Keberadaan Advokat telah diatur dalam Undang-undang Republik Indonesia Nomor 18 Tahun 2003 tentang Advokat. Advokat adalah orang yang berprofesi memberi jasa hukum, baik di dalam maupun di luar pengadilan yang memenuhi persyaratan berdasarkan ketentuan Undang-Undang. Jasa Hukum adalah jasa yang diberikan Advokat berupa memberikan konsultasi hukum, bantuan hukum, menjalankan kuasa, mewakili, mendampingi, membela, dan melakukan tindakan hukum lain untuk kepentingan hukum klien. Klien adalah orang, badan hukum, atau lembaga lain yang menerima jasa hukum dari Advokat.

Berdasar Pasal 5 ayat (1) UU Advokat, disebutkan bahwa, "Advokat berstatus sebagai penegak hukum, bebas dan mandiri yang dijamin oleh hukum dan peraturan perudang-undangan". Dalam penjelasan pasal 5 ayat (1) UU Advokat, dijelaskan bahwa yang dimaksud dengan "Advokat berstatus sebagai penegak hukum" adalah "Advokat sebagai salah satu perangkat dalam proses peradilan yang mempunyai kedudukan yang setara dengan penegak hukum lainnya dalam menegakkan hukum dan keadilan". Keberadaan Advokat sebagai penegak hukum sangat penting khususnya dalam perannya sebagai komponen pendukung terwujudnya sistem peradilan pidana terpadu dalam penegakkan hukum pidana di Indonesia. .

Dari segi bentuk dan tempatnya, terdapat 2 (dua) peran Advokat sebagai penegak hukum dalam mendukung terwujudnya sistem peradilan pidana terpadu dalam penegakan hukum pidana di Indonesia, yakni :

\footnotetext{
${ }^{35}$ Bryan A. Garner, 2009, Black's Law Dictionary Ninth Edition, West, United States of America, hlm. 975.

${ }^{36}$ Bambang Sunggono dan Aries Harianto, 2009, Bantuan Hukum dan Hak Asasi Manusia, Mandar Maju, Bandung, hIm. 9.

${ }^{37}$ Bagir Manan, op.cit., hlm. 69.

${ }^{38}$ Bagir Manan, op.cit., hlm. 281.

${ }^{39}$ Lilik Mulyadi, 2008, Bunga Rampai Hukum Acara Pidana Perspektif, Teoritis dan Praktek, Alumni, Bandung, , hlm. 13-14.
} 
1. Peran Advokat dalam bentuk pendampingan hukum terhadap pelaku yang diatur didalam KUHAP (diatur didalam Undang-undang Republik Indonesia Nomor 8 Tahun 1981 Tentang Hukum Acara Pidana (KUHAP)), dan;

2. Peran Advokat dalam bentuk pendampingan hukum terhadap korban yang diatur diluar KUHAP.

Peran seorang Advokat yang profesional ketika memberikan bantuan hukum bagi para pencari keadilan sangat diperlukan dalam rangka menuju sistem peradilan pidana terpadu hingga tercapai perlindungan terhadap hak-hak azasi manusia. Sistem peradilan pidana yang didukung oleh pengaturan hak bantuan hukum yang memungkinkan komponen Advokat sebagai penegak hukum mampu secara penuh dalam proses peradilan pidana.

\section{Saran}

1. Perlu adanya perubahan terhadap Undang-Undang Republik Indonesia Nomor 18 Tahun 2003 tentang Advokat khususnya pasal mengenai kedudukan dan peran Advokat sebagai penegak hukum agar dapat terlihat lebih jelas.

2. Untuk mendukung terwujudnya Sistem Peradilan Pidana terpadu, perubahan terhadap Kitab Undang-undang Hukum Acara Pidana perlu dilakukan, sebab keberadaanya sebagai hukum formil yang mengatur tentang tata cara pengadilan pidana di Indoneisa. Perlu peningkatan koordinasi dan sinkronisasi para komponen penegak hukum dalam sistem peradilan pidana di Indonesia yakni Polisi, Jaksa, Hakim dan Advokat agar tercipta sistem peradilan pidana yang terintegrasi.

\section{DAFTAR PUSTAKA}

Abdussalam \& DPM Sitompul, 2007, Sistem Peradilan Pidana, Restu Agung, Jakarta.

Ari Yusuf Amir, 2010, Strategi Bisnis Jasa Advokat, cetakan III, Navila Idea, Yogyakarta.

Barda Nawawi Arief, 2017. Reformasi Sistem Peradilan (Sistem Penegakan Hukum Di Indonesia), Badan Penerbit Univ. Diponegoro, Semarang.

Bagir Manan, 2009, Menegakkan Hukum Suatu Pencarian, Asosiasi Advokat Indonesia, Jakarta.

Bambang Sutiyoso, 2010, Refarmasi Keadilan dan Penegakan Hukum di Indonesia, UII Press, Yogyakarta.

Bambang Sunggono dan Aries Harianto, 2009, Bantuan Hukum dan Hak Asasi Manusia, Mandar Maju, Bandung.

Bryan A. Garner, 2009, Black's Law Dictionary Ninth Edition, West, United States of America.

Dyah Octhorina, dan A'an Efendi, 2013, Penelitian Hukum (Legal Research), Sinar Grafika, Jakarta.

Hilman Hadikusuma, 2013, Bahasa Hukum Indonesia, PT Alumni, Bandung.

Ishaq, 2012, Pendidikan Keadvokatan, Sinar Grafika, Jakarta.

Kamus Besar Bahasa Indonesia, Pusat Bahasa, PT Gramedia Pustaka Utama

Komisi Yudisial, 2012, Dialektika Pembaharuan Sistem Hukum Indonesia, Komisi Yudisial, Jakarta.

Lilik Mulyadi, 2008, Bunga Rampai Hukum Acara Pidana Perspektif, Teoritis dan Praktek, Alumni, Bandung.

Muhammad Rusli, 2011, Sistem Peradilan Pidana Terpadu, UII Press, Yogyakarta. 
Nikolas Simanjuntak, 2012, Acara Pidana Indonesia dalam Sirkus Hukum, Ghalia, Bogor Indonesia.

Peter Mahmud Marzuki, 2007, Penelitian Hukum, Kencana, Jakarta.

Romli Atsasmita, 2011, Sistem Peradilan Pidana Kontemporer, cetakan ke 2 , Kencana, Jakarta.

Rusli Muhamad, 2012, Sistem Peradilan Pidana Indonesia : Dilengkapi Dengan 4 Undan-undang di Bidang Sistem Peradilan Pidana, UII Press, Yogyakarta.

Salim HS dan Erlies Septiana Nurbani, 2013, Penerapan Teori Hukum pada Penelitian Tesis dan Disertasi, Raja Grafindo Persada, Jakarta.

Satjipto Raharjo, 2009, Penegakan Hukum di Indonesia (Suatu Tinjauan Sosiologis), Genta Publishing, Yogyakarta.

Soerjono Soekanto dalam Zainuddin Ali, 2011, Metode Penelitian Hukum, Cetakan ke-3, Sinar Grafika, Jakarta.

Sukris Sarmadi, 2009, Advokat (Litigasi dan Non Litigasi Pengadilan), Mandar Maju, Bandung.

Supriadi, 2006, Etika dan Tanggung Jawab Profesi Hukum di Indonesia, Sinar Grafika, Jakarta.

W.J.S Poerwadarminta, 2007, Kamus Umum Bahasa Indonesia, Edisi Ketiga Cetakan keempat, Balai Pustaka, Jakarta.

Yahya Harahap. 2016, Pembahasan Permasalahan dan Penerapan KUHAP, Penyidikan dan Penuntutan, Sinar Grafika, Jakarta,

Bagir Manan, Kedudukan Penegak hukum dalam sistem ketatanegaraan Republik Indonesia, Varia Peradilan ke XXI No.243 Februari 2006.

Gunarto, Agenda Penegakan Hukum dan Relevansinya Bagi Pembangunan Bangsa, Jurnal Pembaharuan Hukum Volume I, No.1, Januari-April 2014.

Lihat Pertimbangan Hukum Putusan MK Nomor 014/PUU-IV/2006 mengenai Pengujian UndangUndang Advokat. 